\title{
Corporate governance and impact on bank performance
}

\author{
Ashenafi Beyene Fanta ${ }^{1,}$,, Kelifa Srmolo Kemal ${ }^{2}$, Yodit Kassa Waka ${ }^{2}$ \\ ${ }^{1}$ Department of Public Financial Management, ECSU, Addis Ababa, Ethiopia \\ ${ }^{2}$ Department of Accounting and Finance, AAU, Addis Ababa, Ethiopia
}

Email adress:

Ashenafizb@gmail.com(A. B. Fanta), kelifasermolo@yahoo.com(K. Srmolo), kyodit@yahoo.com(Y. Kassa)

To cite this article:

Ashenafi Beyene Fanta, Kelifa Srmolo Kemal, Yodit Kassa Waka. Corporate Governance and impact on Bank Performance. Journal of Finance and Accounting. Vol. 1, No. 1, 2013, pp. 19-26. doi: 10.11648/j.jfa.20130101.12

\begin{abstract}
This study aims at examining the corporate governance mechanisms and their impact on performance of commercial banks in the absence of organized stock exchange. The study assessed the relationship between selected internal and external corporate governance mechanisms, and bank performance as measured by ROE and ROA. The study used structured review of documents, and commercial banks financial data were collected covering a period 2005 to 2011 . The findings indicated that board size and existence of audit committee in the board had statistically significant negative effect on bank performance; whereas bank size had statistically significant positive effect on bank performance. Similarly, capital adequacy ratio, as a measure of external corporate governance mechanism, had statistically significant positive effect on bank performance. In addition, absence of organized stock exchange; high government intervention; lack of corporate governance awareness, absence of national standards of corporate governance, as well as accounting and auditing; and weak legal framework to protect minority shareholder rights are the major factors with adverse impact on corporate governance and bank performance in Ethiopia.
\end{abstract}

Keywords: Ethiopia, Banking Sector, Corporate Governance, Bank Performance

\section{Introduction}

Corporate governance is essential due to the separation of ownership and control in publicly held companies. In corporations, shareholders (principals) delegate decision making rights to management (agents), expecting agents to act in the best interest of the principals, however, the "agency problem" arises when the agents do not make their decision to the best interest of the principal or the agents are engaged in self-interest at the expense of shareholders interest [1] and [2]. Therefore, instituting good corporate governance is primarily aimed at minimizing the potential loss of shareholders due to conflict of interest between shareholders and management [3]. As a primary means of reducing this conflict of interest, the shareholders of corporations elect and appoint members of board of directors in order to monitor the actions of management and make strategic decisions about the corporation on behalf of the shareholders.

Good corporate governance improves economic efficiency and growth as well as enhances investor confidence [4]. It also increases access to external financing by firms, lowers cost of capital and increases operational perfor- mance [5]. [6] also indicated that investors are willing to pay large premiums for companies with effective corporate governance. Hence, it can be argued that good corporate governance will lead to increase in firm value as well as better firm performance.

While scholars in advanced economies have developed a fairly sizeable literature on corporate governance, in developing countries there have not been many studies on this topic [7] and [8]. [9] also noted that despite the fact that, previous empirical studies have provided the nexus between corporate governance and firm performance, there is still no consensus on the impact of corporate governance on firm performance. Prior studies conducted in the area of corporate governance in Ethiopia are very scant, and none of the existing studies (e.g [10] and [11]) attempted to analyze the effect of corporate governance on bank performance. Furthermore, it would be interesting to understand how corporate governance is shaped in Ethiopia where there is no capital market.

This study, therefore, examines the effect of internal and external corporate governance mechanisms on bank performance. The study used panel data econometric analysis based on financial and non-financial data collected from all commercial banks in operation from the year 2005 to 2011 . 
The findings indicated that while board size and existence of audit committee in the board had statistically significant negative effect on bank performance, bank size and capital adequacy ratio had statistically significant positive effect on bank performance.

The rest of the paper is organized as follows. Section 2 presents review of related literature. Section 3 describes the data and research methodology. Section 4 deals with results and discussion. Section 5 presents the conclusion and finally Section 6 presents policy implications of the findings.

\section{Literature Review}

\subsection{Review of Theoretical Literature}

Various corporate governance theories have been developed concerning the nature and significance of corporate governance, and they include, inter alia, agency theory, stakeholder theory, and stewardship theory that are briefly described in the ensuing paragraphs.

Agency Theory: Agency theory is widely used as a means of explaining various corporate governance issues. The essence of the theory is based on the existence of separation of ownership and control in large corporations. In such corporations, the managers (agents) are hired to work and make decision on behalf of the owners (principals) in order to maximize return to the shareholders [1]. However, conflict of interest between the agent and the principal inevitably occurs when the agent fails to act in the best interest of the principal, and instead act to maximize their own value [1]. Such conflict of interest occurs due to difference in their preferred level of managerial effort, their attitude towards risk, and their time horizons, which in turn may lead to divergence in the goals of managers and shareholders [3]. Consequently, different control mechanisms either internal or external to the firm should be put in place in order to align the interests of managers and shareholders [3]. Nevertheless, [12] argue that, assumptions made in agency theory about individualistic utility motivation resulting in principal-agent interest divergence may not hold for all managers; and therefore, exclusive reliance on agency theory is undesirable, because the theory ignores the complexities of organizational life.

Stewardship theory: The stewardship theory, on the other hand, originates from sociology and psychology. The stewardship theory maintains that managers are not motivated by individual goals but rather they are stewards, whose motives are aligned with the objectives of their principalsshareholders [12]; as opposed to the agency theory which claims that conflict of interest between managers and shareholders is inevitable unless appropriate structures of control are put in place to align the interests of managers and shareholders [1]. The stewardship perspective suggests that stewards (managers) are satisfied and motivated when organizational success is attained even at the expense of the stewards' personal goals [2]. Furthermore, while the agency theory suggests that shareholder interests will be protected by separating the posts of board chair and CEO, the stewardship theory argues that shareholder interests will be maximized by assigning the same person to the posts of board chair and CEO to give more responsibility and autonomy to the CEO as a steward in the organization [13].

Stakeholder theory: The other popular theory of corporate governance is the Stakeholder theory. The stakeholder theory originated from the management discipline and gradually developed to include corporate accountability to a broad range of stakeholders [2]. Unlike the agency theory, whereby managers are predominantly responsible for satisfying the interests of shareholders, stakeholder theory maintains that managers in organizations are not only responsible for the interests of shareholders but also for a network of relationships to serve which includes the suppliers, employees and business partners [2]. According to stakeholder theory decisions made regarding the company affect and affected by different parties in addition to stockholders of the company. Hence, the managers should on the one hand manage the company to benefit its stakeholders in order to ensure their rights and their participation in decision making and on the other hand the management must act as the stockholder's agent to ensure the survival of the firm to safeguard the long term stakes of each group [14]. Consequently, according to [15] the major debate in corporate governance focuses on whether corporate governance should focus exclusively on protecting the interests of equity holders in the corporation, or should expand its focus to deal with the problems of other stakeholders.

\subsection{Review of Empirical Literature}

Different scholars use different proxies of internal and external corporate governance mechanisms to see their impact on bank performance. Of the internal governance variables, board size and composition are frequently used. Nevertheless, the results of previous studies are inconclusive as presented below. [16] Investigated the effect of governance on the performance of Jordanian commercial banks. He tested the effect of governance mechanisms such as board size, CEO duality, percentage of non-executive directors, capital adequacy, the ownership percentage of large shareholders, and the ownership percentage of the largest shareholder on the bank performance as measured by Tobin's Q. He found that CEO duality, and percentage of nonexecutive directors had statistically significant positive effect on performance; whereas leverage had statistically significant negative effect on performance. And [16] concluded that as CEO duality, percentage of non-executive directors, ownership concentration, and capital adequacy are recognized as effective determinants on banking performance. [17] Also examined the effect of corporate governance on bank performance in Nigeria and found that, contrary to the evidence found by [16], board size as well as chief executive status has a positive effect on performance. Similarly, [18] analyzed the relationship between board composition and corporate performance using 348 Austral- 
ian listed companies. They show that board size and the proportion of inside directors, were significantly positively related to market-based measure of firm performance. These evidences are also supported by [19]; who finds a significant positive relationship between board size and bank performance and significant negative relationship between the level of related-party loans and bank performance. Another dimension of the literature on bank corporate governance and performance has focused on the relationship between external corporate governance mechanisms and bank performance. [20] Extensively investigated the relationship among corporate governance, risk management, and bank performance in Indonesian banking sector. They take capital adequacy ratio (CAR) as the measure of external corporate practice; value at risk (VAR) as the measure of risk management, return on equity (ROE) and net profit margin (NPM) as the measure of bank performance. They found that the relationship between corporate governance and risk management and between corporate governance and bank performance are sensitive to the type of bank ownership. Furthermore, risk management has significant effect on bank performance, and vice versa. They also found nonlinear relationship between CAR and ROE. Similarly, [21] studied the relationship between corporate governance and bank performance in Malaysia during the pre and post Asian Financial Crisis using yearly data of 11 banks for the period $1995-2005$. They found evidence that CAR has significant positive relationship performance. [21] Also found that foreign owned banks have better corporate governance practices than domestically owned private banks. [22] Also tried to address the issue from a slightly different point of view. He investigated the corporate governance and financial performance of selected commercial banks in Uganda from the perspective of bank depositors and bank officials using questionnaire with 5-point Likert Scale to collect data on the perception of 388 respondents. He also used variables such as trust, disclosure, and financial transparency as a measure of corporate governance and CAMEL framework as a measure of bank performance and concluded that trust, disclosure, and transparency have a major positive contribution to the performance of commercial banks. However, his study is marred by methodological flaws related to application of the statistical tools. The foregoing studies suggest that while there is agreement on the idea that good corporate governance improves firm performance, consensus is hard to come by when it comes to the question of how and which corporate governance mechanisms affect firm performance. This makes it imperative that more empirical investigation is conducted on the issue. Furthermore, most previous studies were made in nations where there are capital markets and the findings may not apply to country such as Ethiopia where there is no organized stock exchange market. Hence, this study tries to fill this void in literature by assessing selected internal and external corporate governance mechanisms and their impact on the performance of commercial banks.

\subsection{The Hypotheses}

Corporate governance of banks could be different from corporate governance of other business enterprises due to the existence of depositors in addition to shareholders, and high government regulation in banks [20]. Thus, [15] suggest that a broader perspective of corporate governance ought to be implemented in the case of banks. Bank corporate governance involves internal and external corporate governance mechanisms. Internal corporate governance mechanisms include but not limited to: the structure of board of directors and their effectiveness in monitoring the management of the bank. External corporate governance mechanisms on the other hand include: the government regulations and supervisions, and the market for corporate control [20] and [23].

With regard to internal corporate governance, previous literature focused on analyzing different aspects of board of directors including its size, independence, structure, activity, and compensation to see the effect on performance (e.g. [18] and [17] ) .Consequently, [24] states that the size of the board can be an important governance consideration. The optimal size of board of directors should be established for good corporate governance as well as performance in the firm. Therefore, the first hypothesis is stated as:

H1: There is positive relationship between Board size and bank performance.

As stated in [25] "market regulators, commissions and accountancy bodies have recommended the establishment of audit committees as an important step in improving corporate governance", because, the audit committee assists the board in fulfilling its oversight responsibilities by reviewing the financial information and internal control systems. The second hypothesis is, therefore, stated as:

$\mathrm{H} 2$ : There is positive relationship between existence of audit committee in the board and bank performance.

Good corporate governance is not the result of only internal corporate governance mechanisms, but there are also external corporate governance mechanisms which are important in reducing the agency problem in banks. In the banking sector, the government establishes relatively higher regulation to save the interests of the depositors as well as the general public. In countries like Ethiopia, where there is no capital market, the effect of the market for corporate control on corporate governance may be minimal. Instead the government's regulation and supervision as an external corporate governance mechanism plays major role in the governance of banks. Accordingly, external corporate governance is considered as a mechanism, which places the government's responsibility to control the operations of banks through prevailing bank regulations [20]. Central bank regulation is exercised through the use of various financial ratios of individual banks that include capital adequacy ratio (CAR), loan loss provision (LLP), loan to deposit (LTD), liquid asset to total asset and others. Of these ratios particularly the CAR of individual banks, is a good indicator of the implementation of good corporate govern- 
ance practice in the bank [20]. [26] also found that the implementation of the capital adequacy requirement reduces risk taking behavior of commercial banks. Hence, the third hypothesis can be put as:

H3: There is positive relationship between external corporate governance mechanisms as measured by CAR and bank performance.

In addition to CAR, there are also other models which are related to external corporate governance. These are capital ratio (CR), cash claim on central bank (CCC), secondary reserve ratio (SRR), loan to deposits ratio (LDR), loan loss provision (LLP) and fixed assets and inventories to capital (FAI). Out of these variables capital adequacy ratio (CAR), capital ratio (CR), loan to deposits ratio (LDR), and loan loss provision (LLP) were used in this study as well. Hence, it can be hypothesized that:

H4: There is negative relationship between loan loss provision and bank performance.

H5: There is positive relationship between capital ratio and bank performance.

H6: There is negative relationship between loan to deposit ratio and bank performance.

\section{Data and Methodology}

\subsection{The Data}

Data for this study was obtained from two sources. Audited annual financial statements of the banks covering the period 2005 to 2011 were obtained from the National Bank of Ethiopia (NBE). Data on board characteristics is obtained from each bank in the study. The study included 9 commercial banks of which 2 are state-owned and the rest private. Consequently, this study used panel data of 9 commercial banks for 7 years (63 observations).

\subsection{Methodology}

A quantitative method of data analysis was employed which involved descriptive and inferential statistical analysis and multivariate regression analysis. The descriptive statistics were used to analyze the means and standard deviations of regression variables. In addition, before conducting regression analysis, various tests were conducted for Classical Linear Regression Model (CLRM) assumptions. The following two regression models were used to understand the effect of corporate governance mechanisms on bank performance:

Model 1 ROE $=\mathrm{a} 0+\mathrm{a} 1 \mathrm{BDSZ}+\mathrm{a} 2 \mathrm{AUDC}+\mathrm{a} 3 \mathrm{CAR}+$ $\mathrm{a} 4 \mathrm{CR}+\mathrm{a} 5 \mathrm{LLP}+\mathrm{a} 6 \mathrm{LDR}+\mathrm{a}$ BKSZ + $\mathrm{a} 8 \mathrm{OWTP}+\mathrm{a} 9 \mathrm{CAR}^{2}+\mathrm{E}$.

Model 2 ROA $=\mathrm{a} 0+\mathrm{a} 1 \mathrm{BDSZ}+\mathrm{a} 2 \mathrm{AUDC}+\mathrm{a} 3 \mathrm{CAR}+$ $\mathrm{a} 4 \mathrm{CR}+\mathrm{a} 5 \mathrm{LLP}+\mathrm{a} 6 \mathrm{LDR}+\mathrm{a} 7 \mathrm{BKSZ}+$ $\mathrm{a} 8 \mathrm{OWTP}+\mathrm{a} 9 \mathrm{CAR}^{2}+\mathrm{E}$.

Where:

$R O E$ is the return on equity

\section{$R O A$ return on asset}

$B D S Z$ board size representing the number of directors sitting in the board

$A U D C$ existence of audit committee in the board, dummy variable taking 1 if there is audit committee in the board, and 0 otherwise.

$C A R$ capital adequacy ratio year-end capital of the bank divided by year-end total risk-weighted assets of the bank

LLP loan loss provision allowance for loan loss divided by year-end total loans

$C A R^{2}$ is the square of capital adequacy ratio

This study uses two control variables, namely, ownership type (OWTP) and bank size (BKSZ).

$B K S Z$ is bank size measured as a log of the year-end total assets.

OWTP is ownership type with dummy variable taking 0 if the bank is a state-owned and 0 otherwise.

\subsection{Tests for the Classical Linear Regression Model (CLRM) Assumptions}

A constant term is included in the model to satisfy the first assumption of the CLRM that the expected value of the errors must be zero. The assumption of a constant variance of error terms has been checked via test of heteroskedsticity. Both the $\mathrm{F}$ and $\chi 2$ version of the test statistic reveal that there is no evidence of heteroskedasticity. The third assumption of uncorrelated error terms was checked using the Durbin-Watson (DW) Test. However, the result is inconclusive in this case i.e. the null hypothesis is neither rejected nor accepted. The fourth assumption requires that the regressors should be uncorrelated with the error terms. This assumption is not violated if the first assumption (expected value of errors is zero) is met [27]. CLRM also assumes a normal distribution so that valid estimation of the coefficient parameters could be made, and the residuals are normally distributed. The histogram for residuals is almost bell shaped with mean of $4.70 \mathrm{e}-17$, and standard deviation of 0.049 , and the Jarque-Bera statistic of 4.9 is not significant at $5 \%$; implying that the null of normality is not rejected. Absence of multicollinearity among independent variables has been checked using Pearson's Correlation Matrix, and we found that all regressors except $\mathrm{CAR}$ and $\mathrm{CR}$ (with correlation coefficient of 0.91), have a correlation coefficient less than 0.8. As a remedy for the high correlation between CAR and CR, CR is dropped from the regression model. Finally, Hausman test has been conducted to choose the appropriate panel regression model(i.e fixed effects model (FEM) or random effects model (REM), and REM selected. 


\section{Results and Discussion}

\subsection{Descriptive Statistics}

Table 4.1 presents the descriptive statistics for the varia- bles in the study based on panel data of the banks from the year 2005 to 2011 . The table presents the mean, and standard deviation including minimum and maximum values of regression variables.

Table 1. Descriptive Statistics of regression variables

\begin{tabular}{|c|c|c|c|c|c|c|c|c|}
\hline \multirow[t]{2}{*}{ Variable } & \multicolumn{2}{|c|}{ State $(\mathrm{N}=14)$} & \multicolumn{2}{|c|}{ Private $(\mathrm{N}=49)$} & \multicolumn{2}{|c|}{ Total sample $(\mathrm{N}=63)$} & \multirow[b]{2}{*}{ Min } & \multirow[b]{2}{*}{ Max } \\
\hline & Mean & Std.Dev. & Mean & Std.Dev. & Mean & Std.Dev. & & \\
\hline ROE & 0.36 & 0.10 & 0.24 & 0.10 & 0.27 & 0.11 & -0.04 & 0.55 \\
\hline ROA & 0.03 & 0.01 & 0.03 & 0.01 & 0.03 & 0.01 & -0.02 & 0.05 \\
\hline CAR & 0.13 & 0.04 & 0.25 & 0.19 & 0.23 & 0.18 & 0.08 & 1.25 \\
\hline CR & 0.31 & 0.09 & 0.32 & 0.17 & 0.31 & 0.15 & 0.14 & 0.98 \\
\hline BDSZ & 7.79 & 2.33 & 9.65 & 1.84 & 9.24 & 2.09 & 5.00 & 12.00 \\
\hline AUDC & 0.50 & 0.52 & 0.65 & 0.48 & 0.62 & 0.49 & 0.00 & 1.00 \\
\hline OWTP & 0.00 & 0.00 & 1.00 & 0.00 & 0.78 & 0.42 & 0.00 & 1.00 \\
\hline LLP & 0.11 & 0.06 & 0.04 & 0.02 & 0.05 & 0.04 & 0.00 & 0.21 \\
\hline LDR & 0.65 & 0.30 & 0.70 & 0.19 & 0.69 & 0.22 & 0.20 & 1.30 \\
\hline BKSZ & 23.15 & 1.66 & 21.91 & 0.96 & 22.18 & 1.25 & 18.68 & 25.46 \\
\hline
\end{tabular}

The descriptive statistics indicates that private banks have mean CAR of $25 \%$, compared to $13 \%$ for state-owned banks, implying that private banks tend to be a bit more cautious about capital adequacy. The average CAR for entire banking sector is $23 \%$, which is above the minimum CAR of $8 \%$ required by both the NBE and Basel Accord. With a mean board size (BDSZ) of 9.65, compared to 7.79 for state-owned banks, private banks have a larger board that their state-owned counterparts. Regarding existence of audit committee in the board of directors (AUDC), on average all of the sample banks have AUDC $49 \%$ of the time during the study period. This is because some of the banks have established audit committee very recently and some don't have it at all.

The mean loan loss provision (LLP) for the state-owned banks and private banks and total sample banks is $11 \%$ and $4 \%$ respectively. These indicate that private bank management is more risk averse than state-owned banks. State-owned banks have mean loan to deposit ratio (LDR) of $65 \%$, compared to $70 \%$ for private banks, signifying a higher degree of reliance of private banks on the depositors fund to make loan. Bank size (BKSZ), shows that state-owned banks have larger mean total assets (23.15) than private banks (21.91), which is partly due to the fact that the largest bank in the sample is a state-owned bank. Finally, with ROE of $36 \%$ state-owned banks have a better performance compared to private banks that have mean ROE $24 \%$. However, the two types of banks have equal performance when measured in terms of average ROA (i.e. $3 \%$ ). In general, the descriptive statistics show that the private banks have higher CAR, CR, and AUDC as well as lower LLP than state-owned banks; suggesting that private banks tend to be more concerned about implementing good corporate governance.

\subsection{Regression Results}

The multiple regression results of the study are presented in table, 4.2 and table 4.3 for model 1 and model 2 respectively. The regression output in Table 4.1 is run by taking ROE as a dependent variable and other governance and control variables as regressors. The regression output reveals that the dependent variable is well explained by the explanatory variables in the model with R-square and adjusted R-square of 0.68 and 0.63 respectively. The F- statistic of 14.57 is also significant with P- value of zero, suggesting that variations in the dependent variable are adequately explained by the regressors in the model.

Table 2. Regression Result for Model 1

\begin{tabular}{lllll}
\hline Variable & Coefficient & Std. Error & t-Statistic & Prob. \\
\hline CAR & -0.4418 & 0.1847 & -2.3917 & $0.0203 * *$ \\
BDSZ & -0.0107 & 0.0049 & -2.1964 & $0.0324 * *$ \\
AUDC & -0.0437 & 0.0191 & -2.2876 & $0.0261 * *$ \\
OWTP & 0.0199 & 0.0340 & 0.5852 & 0.5609 \\
LLP & 0.1663 & 0.2876 & 0.5784 & 0.5654 \\
LTD & 0.0933 & 0.0582 & 1.6049 & 0.1143 \\
BKSZ & 0.0644 & 0.0134 & 4.7968 & $0.0000^{* * * *}$ \\
CAR2 & 0.3070 & 0.1449 & 2.1186 & $0.0387 * *$
\end{tabular}




\begin{tabular}{lcc} 
R-squared & 0.683372 & \\
Adjusted R-squared & 0.636465 & \\
S.E. of regression & 0.068468 & \\
F-statistic & $14.56842 \quad$ Durbin-Watson stat & 1.67706 \\
Prob(F-statistic) & 0.0000 & \\
\hline$* * * * *$ indicates significant at 1\%, and 5\% significance level respectively.
\end{tabular}

The regression results in Table 4.2 show that explanatory variables such as capital adequacy ratio (CAR), board size (BDSZ), and existence of audit committee (AUDC) have a statistically significant negative effect on bank performance while square of capital adequacy ratio $\left(\mathrm{CAR}^{2}\right)$ and bank size (BKSZ) have a statistically significant positive effect on performance measured using ROE.

The second model where we have ROA as a dependent variable has following regression results:

Table 3. Regression Result for Model 2

\begin{tabular}{|c|c|c|c|c|}
\hline Variable & Coefficient & Std. Error & t-Statistic & Prob. \\
\hline $\mathrm{C}$ & -0.06624 & 0.036312 & -1.82405 & $0.0737 *$ \\
\hline CAR & 0.044593 & 0.019324 & 2.307658 & $0.0249 * *$ \\
\hline BDSZ & -0.00111 & 0.000508 & -2.185153 & $0.0332 * *$ \\
\hline AUDC & -0.00512 & 0.001999 & -2.559854 & $0.0133 * *$ \\
\hline OWTP & 0.005264 & 0.003561 & 1.478264 & 0.1451 \\
\hline LLP & -0.02403 & 0.030083 & -0.798607 & 0.428 \\
\hline LDR & 0.004289 & 0.006084 & 0.70495 & 0.4839 \\
\hline BKSZ & 0.004365 & 0.001404 & 3.109833 & $0.003 * * *$ \\
\hline CAR2 & -0.05742 & 0.01516 & -3.787429 & $0.0004 * * *$ \\
\hline \multicolumn{5}{|l|}{ Weighted Statistics } \\
\hline R-squared & 0.522226 & & & \\
\hline Adjusted R-squared & 0.451445 & & & \\
\hline S.E. of regression & 0.009279 & & & \\
\hline F-statistic & 7.378017 & \multirow{2}{*}{\multicolumn{2}{|c|}{ Durbin-Watson stat }} & 1.307614 \\
\hline Prob(F-statistic) & 0.000001 & & & \\
\hline
\end{tabular}

$* * *, * *, *$ indicate significant at $1 \%, 5 \%$, and $10 \%$ significance level respectively.

The adjusted $\mathrm{R}^{2}$ for this regression is 0.45 ; indicating that the regressors in Model 2 can explain $45 \%$ of the variation in the dependent variable (ROA). The F- statistic for the regression is also significant at zero P-value to five decimal places. This shows there is still a good explanatory power of the regressors in the model. The regression results in Table 4.3 reveal that all the significant variables in the previous regression (Table 4.2) are still significant. Capital adequacy ratio, board size, as well as existence of audit committee are statistically significant at 5\%; whereas the squares of capital adequacy ratio and bank size are statistically significant at $1 \%$. On the other hand, loan loss provision, loan to deposit ratio, and ownership type do not have a statistically significant effect on performance. However, the coefficients of CAR, CAR ${ }^{2}$ and LLP have changed signs.

\subsection{Discussion on Findings}

The results of model 1 revealed that there is inverse relationship between CAR and ROE. This result is consistent with the findings of [20], who argue that the effect of CAR on ROE may not be linear due to central bank regulation. The central bank requires banks to maintain CAR level of at least $8 \%$ to protect the depositors' interest. So, the negative effect of CAR on ROE will turn in to positive when
CAR exceeds the particular amount of which depositors perceive and believe that bank will be concerned about implementing good corporate governance; then they will be interested to deposit their money as well as buy the shares of the bank, leading to profitability of the bank. $\mathrm{CAR}^{2}$ was introduced to address this issue, and it has been discovered that $\mathrm{CAR}^{2}$ has a positive effect on ROE.

Board size has an adverse effect on performance, suggesting that banks with larger boards tend to perform poorly compared to banks with smaller boards. This is consistent with findings of [17], who found a negative relationship between board size and bank performance, though it contradicts the findings of [18] and [19] who found a positive relationship between board size and bank performance. Adverse effect of board size on bank performance may be due to the fact that boards with too many directors could be unproductive, with ineffective communication among directors in the board [24]. This leads to director free riding problem i.e. directors consume more resources than they contribute to the bank, and thereby reducing bank performance.

The effect of existence of audit committee (AUDC) on bank performance (ROE) is also negative, suggesting that banks having a designated audit committee in the board perform worse than those without. This result contradicts our hypothesis that posited a positive effect of audit com- 
mittee on performance following [25]. Nevertheless, the negative effect of audit committee on bank performance could be attributed to the audit committee members' lack of expertise in helping the board in the governance of the bank, leading to mere increase in board size and board of directors' fee.

Bank size (BKSZ) has a positive effect on bank performance (ROE), implying large banks enjoy better profits than smaller banks. This benefit is likely to be due to economies of scale and larger market share possessed by the larger banks, and this is consistent with the findings of [28].

The regression result of model 2 shows that CAR has a positive effect on ROA, suggesting that external corporate governance of a bank improves performance. This is consistent with the expectation and is also supported by the finding of both [21] as well as [29]. Consistent to the results obtained from regression Model 1, board size has a negative effect on bank performance. Similarly, audit committee in the board (AUDC) is found to have a negative effect on bank performance. Bank size (BKSZ) has a positive effect on bank performance (ROA), which agrees with the results of model 1 .

Ownership type (OWTP), loan loss provision (LLP) and loan to deposit ratio (LDR) are found to have no significant effect on bank performance. This implies that the size of loan loss provision as a measure of management's risk taking behavior does not have any significant effect on bank profitability. This situation may be due to the fact that the size of loss due to risk of uncollectible loans is equally compensated by the income from loans made. This contradicts the hypothesis that there is negative relationship between loan loss provision and bank performance. Similarly, contrary to our hypothesis, the magnitude of loan to deposit ratio does not significantly affect bank performance; suggesting that the source of funds (depositors or shareholders) for making loan does not matter to a bank's performance. Furthermore, the type of ownership of the bank (state-owned or private) does not affect the bank's profitability significantly. This result is also supported by [30] who found insignificant difference between performance of state-owned and private banks in Ethiopia. The fact that the data did not support the general idea that privately owned firms in general perform well as compared to stated-owned ones. This might be due to the fact that leadership, management and operation systems of the Ethiopian private banks are replications of the state-owned ones. Especially, almost all people holding higher, middle and lower managerial positions in private banks came from the state-owned banks which replicate the bureaucracy and management systems they had in the state-banks. There is no difference between the private and state banks in terms of the type and quality of service both provide.

\section{Conclusion}

The result of the two regression models revealed consistent evidence. CAR as a proxy of external corporate governance has positive relationship with bank performance indicating that better corporate governance leads to better bank performance. The effect of CAR on ROE is non-linear due to government regulation. Hence, the negative effect of CAR on ROE is expected to turn in to positive when CAR increases to a certain level where the financial health of the bank improves. On the other hand, the size of board of directors negatively affects the profitability of the bank, implying that the less the number of directors in the board, the better profitable a bank becomes. Similarly, existence of audit committee in the board has adverse impact on the profitability of the bank while the size of the bank is an important factor with a positive contribution to its profitability. Bank profitability is not affected by the proportion of loan loss provision. This appears to mean managers who take more risk of loss due to uncollectible loans are equally compensated by the income from loans made. Similarly, the level of a bank's reliance on the depositors' fund to make loan has no impact on the banks profitability. And finally, whether a bank is owned by the state or the private investors its profitability will be basically the same.

\section{Policy Implications}

Empirical findings reveal that as a means to strengthen the performance of commercial banks in Ethiopia, the government or National Bank of Ethiopia should be concerned about the level of both internal and external corporate governance mechanisms of banks. The findings also suggest that shareholders should actively take part in establishing good corporate governance in the banks they own in order to earn better and sustainable profits. The National Bank of Ethiopia should encourage banks to implement good corporate governance practices through enacting rules and regulations. Keeping the number of director in a bank board to a minimum size is recommended, so long as that minimum size enables the board to perform its supervision activities properly. Commercial banks should increase their branches as well as their size in order to improve profitability due to economies of scale. The government, and financial institutions as well as the business community should work towards the establishment of a formal capital market institutions especially stock exchange which enhances corporate governance, and competition among businesses in the country. Finally, future research should focus on assessing corporate governance mechanisms and firm performance from the perspective of different stakeholders such as employees, management, shareholders and depositors of commercial banks. 


\section{References}

[1] Jensen, MC \& Meckling, WH 1976, 'A Theory of the firm: governance, residual claims, and organizational forms', Journal of Financial Economics, vol. 3, no. 4, pp. 305-360, Harvard University Press.

[2] Abdullah, H \& Valentine, B 2009, 'Fundamental and ethics theories of corporate governance', Middle Eastern Finance and Economics Journal, Issue 71 (2009).

[3] Bozec, Y \& Bozec, R 2007, 'Ownership concentration and corporate governance practice: substitution expropriation effects', Canadian Journal of Administrative Science, no. 24, pp.182-195

[4] Organization for Economic Co-operation and Development (OECD) 2004, 'The OECD Principles of corporate governance', OECD Publications Service, France.

[5] Claessens, S 2003, 'Corporate governance and development' The International Bank for Reconstruction and Development / World Bank.

[6] Coombes, P \& Watson, M 2000, 'Three surveys on corporate governance', The McKinsey Quarterly, no. 4, 2000

[7] Dahawy, K 2007, Developing nations corporate governance: the story of Egypt', The American University in Cairo.

[8] Okpara, J 2010 'Perspective on corporate governance challenges in a Sub-Saharan economy' Journal of Business \& Policy Research, vol. 5, no. 1, pp. $110-122$.

[9] Babatunde, A \& Olaniran, O 2009, 'The Effects of internal and external mechanism on governance and performance of corporate firms in Nigeria' Journal of Corporate Ownership \& Control, vol. 7, no. 2, winter

[10] Minga, N 2008, 'Rethinking corporate governance in Ethiopia', African Peer Review Mechanism, Working Paper Series, Paper for a conference on corporate governance in Africa, September 2008.

[11] Fekadu, G 2010, 'Emerging separation of ownership and control in Ethiopian share companies: legal and policy

[12] Davis, J, Schoorman, D \& Donaldson, L 1997, 'Toward a stewardship theory of management' Academy of Management Review, vol. 22, no. 1.

[13] Donaldson, L \& Davis, H 1991, 'Stewardship theory or agency theory: CEO governance and shareholder returns', Australian Journal of Management, vol. 16, no. 1, University of New South Wales.

[14] Fontaine, C, Haarman, A and Schmid, S 2006 'The Stakeholder theory: stakeholder theory of the MNC' (No volume \& number).

[15] Macey, M \& O'Hara, JR 2003, 'The Corporate governance of banks', FRBNY Economic Policy Review, Cornell University, April 2003.

[16] Al-Hawary, S 2011, 'The Effect of banks governance on banking performance of the Jordanian commercial banks
Tobin's q model' International Research Journal of Finance and Economics, no. 71 (2011).

[17] Sunday K. 2008 'Corporate governance and firm performance: The Case of Nigerian Listed firms' European Journal of Economics, Finance and Administrative Sciences, Issue 14 (2008).

[18] Kiel, G \& Nicholson, G 2003, 'Board composition and corporate performance: how the Australian experience informs contrasting theories of corporate governance', An International Review, vol. 11, no. 3, pp. 185-205.

[19] Yung, CM 2009, 'The Relationship between corporate governance and bank performance in Hong Kong', Master Dissertation paper, Auckland University of Technology, China.

[20] Tandelilin, E, Kaaro, H, Mahadwartha, PA, \& Supriyatna 2007, 'Corporate governance, risk management, and bank performance: Does type of ownership matter?', EDAN Working Paper, no. 34 (2007).

[21] Kim, P \& Rasiah, D 2010, 'Relationship between corporate governance and bank performance in Malaysia during the pre and post Asian financial crisis', European Journal of Economics, Finance and Administrative Sciences, no. 21 (2010).

[22] Rogers, M 2008, 'Corporate governance and financial performance of selected commercial banks in Uganda', Paper presented at CRRC 2008, Queen's University, Belfast 7-9 September 2008.

[23] Weir, C, Laing, D, and McKnight, PJ 2000, 'Internal and External Governance Mechanisms: Their Impact on the Performance of Large UK public companies', Journal of Business Finance \& Accounting, vol. 29, no. 5 \& 6 .

[24] Dallas, G 2004, Governance and Risk: An Analytical Handbook for Investors, Managers, Directors, \& Stakeholders, McGraw-Hill Inc.,U.S.

[25] Waweru, MN, \& Kamau, RG, Uliana, E, 2008, 'Audit committees and corporate governance in a developing country', AAA 2009 Management Accounting Section (MAS) Meeting Paper.

[26] Konishi, M \& Yasuda, Y 2004, 'Factors affecting bank risk taking: Evidence from Japan', Journal of Banking \& Finance, no. 28 (2004), pp. 215-232.

[27] Brooks, C 2008, introductory econometrics for finance, 2nd edn, Cambridge University Press, U.K.

[28] Bino, A \& Tomar, S 2008, 'Corporate governance and bank performance: evidence from Jordanian banking industry', Jordan Journal of Business Administration, University of Jordan, (No volume. and number).

[29] Fukuda, S, Kasuya, M and Nakajima J 2005, 'Bank health and investment: An Analysis of unlisted companies in Japan', CIRJE Discussion Papers, University of Tokyo.

[30] Semu, Z 2010, 'Impact of reducing loan by Ethiopian banks on their own performance', Master's Thesis, University of South Africa. Unpublished. 